\title{
Antioxidative Properties of 34 Green Leafy Vegetables
}

\author{
K.D.P.P.Gunathilake ${ }^{1,2}$ \& K.K.D.S.Ranaweera ${ }^{2}$
}

1. Department of Food Science \& Technology, Faculty of Livestock, Fisheries \& Nutrition, Wayamba University of Sri Lanka, Makandura, Gonawila, Sri Lanka

2. Department of Food Science and Technology, Faculty of Applied Sciences, University of Sri Jayewardenepura, Gangodawila, Nugegoda, Sri Lanka 


\title{
Antioxidative Properties of 34 Green Leafy Vegetables
}

\begin{abstract}
Green leafy vegetables available in Sri Lanka have not been fully exploited though they are stipulated to be rich sources of natural antioxidant. This study examined the antioxidant properties of thirty four edible green leafy vegetables popular in Sri Lanka. Methanolic extracts of leafy vegetables were analyzed for total phenolic, carotene and chlorophyll content and were evaluated for total antioxidant capacity, reducing power, lipid peroxidation and DPPH radical scavenging assays. The results indicated that these leafy vegetables have remarkable variations in their antioxidant activities. Among the plant materials screened for their antioxidant properties, Sesbania grandiflora, Cassia auriculata, Murraya koenigii Spreng, Passiflora edulis, Gymnema lactiferum and Olax zeylanica, showed high carotene content, antioxidant activities and polyphenolics compared to other leaf varieties tested. A good correlation was observed between antioxidant assays and polyphenolics of the leafy vegetables.
\end{abstract}

Keywords: Green leafy vegetables, polyphenolics, antioxidant activities, reducing power, carotene 


\subsection{Introduction}

2 Many chronic diseases such as cancer and cardiovascular diseases represent an increasing 3 proportion of morbidity and mortality in the developing countries, including Sri Lanka. Various

4 research findings have demonstrated that changes in oxygen utilization in the body and increased

5 formation of reactive oxygen species (ROS) contribute to many chronic diseases (Kaliora et al.,

6 2006; Madamanchi et al., 2005). Though an organism is naturally equipped with antioxidant

7 protection systems to cope with the harmful effects of ROS, the endogenous antioxidant defense

8 system is not totally adequate to counteract the oxidative stress (Houston, 2010). Therefore,

9 protection against oxidative stress depends partly on the adequacy of dietary antioxidants

10 (Kaliora et al., 2006). Evidence suggests that phytochemicals from fruits and vegetables

11 including, leafy vegetables, are capable of providing protection against free radicals. Therefore, a

12 greater deal of research has been focused on natural antioxidants and it is necessary to screen the

13 natural sources for their antioxidant potential.

14 Green leafy vegetables constitute a major part of any balanced diet and contain significant 15 amounts of minerals and antioxidant vitamins (Subhasree et al., 2009). Various research findings 16 have suggested that leafy vegetables have medicinal properties such as anticarcenogenic

17 (Rajeshkumar et al., 2002), antibacterial (Kubo et al., 2004) and antidiabetic (Kesari et al., 2005)

18 effects. These health benefits of green leafy vegetables are attributed, at least in part, to their

19 antioxidants. Recently, research has indicated that green leafy vegetables are rich sources of

20 functional components. The major active antioxidant compounds are polyphenolic constituents

21 and carotenoids, among others (Subhasree et al., 2009; Andarwulan et al., 2012; Khanam et al.,

22 2012; Deng et al., 2013). Lutein is one of the major carotenoids in green leafy vegetables which 23 show a marked antioxidant activity (Chandrika et al., 2010). However, most of the green leafy 
24 vegetables available in Sri Lanka represent a class of underexploited plants that are stipulated to

25 be rich sources of natural antioxidants.

26 A great number of in vitro assay methods have been developed to evaluate the efficiency of

27 natural antioxidants. These methods include measurement of phenolic content using Folin-

28 Ciocalteu assay, reducing power assay, total antioxidant capacity assay, lipid peroxidation assay 29 and 2,2-diphenyl-1-picrylhydrazyl (DPPH) radical-scavenging assay. The above in vitro methods

30 can be used for the screening of green leafy vegetables commonly available in Sri Lanka. The 31 purpose of this study was to examine the antioxidant characteristics of thirty four edible green

32 leafy vegetables popular in Sri Lanka. The results of this study can be useful for food industry 33 and in preventive medicine in the development of "natural antioxidants"/nutraceuticals from 34 plant sources.

\subsection{Materials and method}

\section{$37 \quad$ 2.1. Materials}

38 Thirty four types of fresh green leafy vegetable samples were collected from various places in 39 Colombo, Negambo and Makandura areas of Sri Lanka. The plant specimens were taxonomically identified by a botanist (Dr. H.D.D.Bandupriya) and the voucher specimens of the

41 samples were deposited in the herbarium of the Department of Food Science and Technology of 42 Wayamba University of Sri Lanka.

\section{$43 \quad$ 2.2. Reagents}

44 Gallic acid, 2,2-diphenyl-2-picrylhydrazyl, Folin-Ciocalteu reagent, ethanol, methanol, sodium 45 phosphate, ammonium molybdate, potassium ferricyanide, phosphate buffer, trichloroacetic acid, 46 ferric chloride, ferrous sulphate, acetic acid, thiobarbituric acid, sodium dodecyl sulphate, 
47 butanol and sodium carbonate were obtained from Sigma Aldrich, St. Louis, MO, USA through 48 Analytical Instrument Pvt Ltd, Colombo, Sri Lanka. All other chemicals used were of analytical 49 grade.

$50 \quad$ 2.3. Preparation of crude extracts

51 Edible portions of the leaves were cleaned with distilled water and air dried at room temperature $52\left(30 \pm 2{ }^{\circ} \mathrm{C}\right)$ for 2 hours. The leaves samples were then oven dried at $45{ }^{\circ} \mathrm{C}$ to a constant weight. 53 One gram of air dried sample from each of these thirty four leafy vegetables was mixed with 20 $54 \mathrm{ml}$ of methanol and vortexed at high speed for five minutes and then centrifuged (Hettich, EBA 55 20) for $10 \mathrm{~min}$ at $792 \mathrm{~g}$. The extracts were subsequently filtered through a filter paper 56 (Whatman No. 42; Whatman Paper Ltd, Maidstone, UK) and the prepared extracts were stored at $57-18{ }^{\circ} \mathrm{C}$ until assayed within 1 week.

\subsection{Determination of total phenolic content}

59 The total phenolic content was determined using Folin-Ciocalteu assay of Singleton et al., 60 (1999) with some modification, as described by Gunathilake and Rupasinghe (2014). About 0.5

$61 \mathrm{~mL}$ of extract and $0.1 \mathrm{~mL}$ of Folin-Ciocalteu reagent $(0.5 \mathrm{~N})$ were mixed and incubated at room 62 temperature for $15 \mathrm{~min}$ in the dark. Then $2.5 \mathrm{~mL} 7.5 \%$ sodium carbonate were added to the 63 mixture and further incubated for 2 hours in the dark at room temperature and then the 64 absorbance were measured at $760 \mathrm{~nm}$ using a UV/VIS spectrometer (Optima, SP-3000, Tokyo, 65 Japan). The concentration of total phenols was expressed as $\mu \mathrm{g}$ gallic acid equivalents (GAE) per $66 \mathrm{~g}$ dry weight of leaf. Gallic acid was used in the construction of standard curve and the linear 67 range used for the calibration curve was 1000-15000 $\mu \mathrm{g}$ GAE/L. 
70 The chlorophyll and carotene contents were analyzed according to the method described by

71 Türlerinde et al. (1998). The weighed samples were mixed with 96\% methanol (50 mL for each

72 gram) for one minute using a vortex. The homogenate was filtered through a filter paper (No: 42

73 Whatman) and centrifuged using the centrifuge (EBA20) for $10 \mathrm{~min}$ at $245 \mathrm{~g}$. The supernatant

74 was separated and the absorbance was read at 470, 653, $666 \mathrm{~nm}$ on UV/VIS spectrometer (SP$753000)$.

76 The concentration of each pigment was calculated according to the formulas of Kichtenthaler

77 and Wellburn (1983) and was reported as $\mu \mathrm{g}$ per g dry weight of sample.

$78 \quad$ Chlorophyl $\mathrm{a}=11.75(\mathrm{~A} 662)-2.350(\mathrm{~A} 645)$.

79 Chlorophyl $b=18.61($ A645) $-3.960($ A662).

$80 \quad$ Carotene $=1000(\mathrm{~A} 470)-2.270\left(\mathrm{C}_{\mathrm{a}}\right)-81.4\left(\mathrm{C}_{\mathrm{b}}\right) / 227$

81 where $\mathrm{C}_{\mathrm{a}}$, Chlorophyll a and $\mathrm{C}_{\mathrm{b}}$, chlorophyll $\mathrm{b}$;

$82 \quad$ 2.6. DPPH Radical Scavenging assay

83

84 The capacity of prepared extracts to scavenge the 'stable' free radical DPPH was monitored

85 according to the method of Hatano et al. (1988) with slight modifications. Extracts (100 $\mu \mathrm{L})$

86 were dissolved in $3.9 \mathrm{~mL}$ freshly prepared methanolic solution of DPPH (1 mM, $0.5 \mathrm{~mL})$. The

87 mixture was vortexed for 15 seconds and then left to stand at room temperature for $30 \mathrm{~min}$ in the

88 dark. The absorbance of the resulting solution was read spectrophotometrically (UV/VIS

89 spectrometer (SP-3000, OPTIMA INC, Japan) at $517 \mathrm{~nm}$. The percentage inhibition of the

90 radicals due to antioxidant activity of leaf extracts was calculated using following formula.

$91 \%$ inhibition $\left.=\left\{\left(\mathrm{A}_{\text {control }}-\mathrm{A}_{\text {sample }}\right) / \mathrm{A}_{\text {control }}\right)\right\} * 100$

$92 \mathrm{~A}_{\text {control }}$ is the absorbance of the DPPH solution with nothing added (control). 
The reducing power of the prepared extracts was determined according to the method of Oyaizu (1986). Briefly, each extract (1 mL) was mixed with $2.5 \mathrm{~mL}$ of a $0.2 \mathrm{M}$ phosphate buffer $(\mathrm{pH}$ 6.6) and $2.5 \mathrm{~mL}$ of a $1 \%(\mathrm{w} / \mathrm{v})$ solution of potassium ferricyanide. The mixture was incubated in a water bath at $50{ }^{\circ} \mathrm{C}$ for $20 \mathrm{~min}$ and then $2.5 \mathrm{~mL}$ of $10 \%(\mathrm{w} / \mathrm{v})$ trichloroacetic acid solution was added and the mixture was then centrifuged for $10 \mathrm{~min}$ at $352 \mathrm{~g}$. A $2.5 \mathrm{~mL}$ aliquot of the upper layer was combined with $2.5 \mathrm{~mL}$ of distilled water and $0.5 \mathrm{~mL}$ of $0.1 \%(\mathrm{w} / \mathrm{v})$ ferric chloride solution. Absorbance of the reaction mixture was read using UV/VIS spectrometer (SP-3000) at $700 \mathrm{~nm}$. Mean values from three independent samples were calculated for each extract.

\subsection{Lipid peroxidation assay}

A modified thiobarbituric acid reactive substances (TBARS) assay was used to measure the level of lipid peroxide formed in egg homogenates as lipid-rich media as described in Ohkowa et al. (1979). Briefly $0.5 \mathrm{~mL}$ egg homogenate $(10 \%$, v/v) was mixed with $0.1 \mathrm{~mL}$ leaf extract, $0.4 \mathrm{~mL}$ distilled water and $0.05 \mathrm{~mL}$ ferrous sulphate $(0.07 \mathrm{M})$ and the mixture was incubated at room temperature for $30 \mathrm{~min}$. After incubation, $1.5 \mathrm{~mL} 20 \%$ acetic acid $(\mathrm{pH}=3.5), 1.5 \mathrm{~mL} \mathrm{0.8 \% (w/v)}$ thiobarbuturic acid (in 1.1\% sodium dodecyl sulphate) and $0.05 \mathrm{~mL} 20 \%$ trichloroacetic acid were added and the mixture was mixed and was heated at $95{ }^{\circ} \mathrm{C}$ for $60 \mathrm{~min}$. After cooling to room temperature, $5.0 \mathrm{~mL}$ butanol was added and centrifuged at $528 \mathrm{~g}$ for $10 \mathrm{~min}$. Absorbance of the mixture was read using UV/VIS spectrometer (SP-3000) at $532 \mathrm{~nm}$. Percentage inhibition of lipid peroxidation by leaves extracts was calculated.

\subsection{Total antioxidant capacity}

The total antioxidant capacity of leaf extracts were analyzed according to the method described by Prieto et al. (1999). The tubes containing leaf extract $(0.3 \mathrm{~mL})$ and $3 \mathrm{~mL}$ reagent solution $(0.6$ M sulphuric acid, $28 \mathrm{mM}$ sodium phosphate and $4 \mathrm{mM}$ ammonium molybdate) were incubated at 
$12195^{\circ} \mathrm{C}$ for $90 \mathrm{~min}$. After the mixture had cooled to room temperature, the absorbance of each

122 solution was measured at $695 \mathrm{~nm}$ spectrophotometrically (UV/VIS-SP-3000) against a blank.

123 The antioxidant capacity was expressed as ascorbic acid equivalents (AAE).

\section{$124 \quad 2.10$. Statistical Analyses}

125 All data from the study were presented as mean \pm standard deviation of three replications. The 126 assumptions of normality were tested using the Anderson Darling test and constant variance 127 using residual versus fits, and the independent assumptions were achieved through 128 randomizations. Samples were analyzed in triplicate and one way analysis of variance (ANOVA) 129 was performed, using general linear model (SAS 9.2, Cary, NC, USA). Differences were 130 considered to be statistically significant if the probability values were less than $0.05(\mathrm{p}<0.05)$. 131 When there were significant differences, multiple mean comparisons were carried out using LSD 132 method. To evaluate the relationship between the antioxidant activities and phenolic and 133 carotene contents, the Pearson correlation coefficient analysis were performed using MINITAB 13417.

\subsection{Results}

136 Total phenolics, chlorophyll and carotene contents of 34 leafy vegetables were analyzed and the

137 results are summarized in Table 1. Total phenolic content of the methanolic extracts of leafy 138 vegetables were within the range of $0.92 .0-11.03 \mathrm{mg}$ GAE/g dry weight of leaf. Of the leafy 139 vegetables studied, Gymnema lactiferum and Sesbania grandiflora, leaves showed the highest 140 total phenolic contents (11.03 and $10.98 \mathrm{mg} \mathrm{GAE} / \mathrm{g}$ dry weight of leaf respectively), followed by 141 Cassia auriculata leaves (10.70 mg GAE/g dry weight). Other leafy vegetables with relatively 142 high antioxidant activities were Passiflora edulis (9.23 mg GAE/g dry weight), Murraya koenigii 143 Spreng (8.71 mg GAE/g dry weight) and Hemidesmus indicus (8.18 mg GAE/g dry weight). 
144 However, among the leaves studied, Asteracantha longifolia (0.92 mg GAE/g dry weight) and 145 Alternathera sessilis (0.98 mg GAE/g dry weight) contained a significantly lower phenolic 146 content.

147 Chlorophyll content in leafy vegetables ranged from 9.20 to $37.10 \mu \mathrm{g} / \mathrm{g}$ dry weight. Boerhavia 148 diffusa $(9.20 \mu \mathrm{g} / \mathrm{g})$, Alternathera sessilis $(9.55 \mu \mathrm{g} / \mathrm{g})$, Allium cepa $(9.45 \mu \mathrm{g} / \mathrm{g})$ and Amaranthus 149 caudatus $(11.37 \mu \mathrm{g} / \mathrm{g})$ showed significantly lower chlorophyll content, whereas Asteracantha 150 longifolia $(37.10 \mu \mathrm{g} / \mathrm{g})$ had the highest chlorophyll content. Carotene content of studied leafy 151 vegetables was within the range of $0.47-4.17 \mathrm{mg} / \mathrm{g}$ dry weight. Among the leafy vegetables 152 analyzed, Passiflora edulis had the highest carotene content (4.17 $\mathrm{mg} / \mathrm{g}$ ) followed by Cassia 153 auriculata (3.45 mg/g), Solanum nigrum $(3.18 \mathrm{mg} / \mathrm{g})$ and Syngonium angustatum $(3.13 \mathrm{mg} / \mathrm{g})$.

154 The lowest carotene content was observed in Alternathera sessilis $(0.47 \mathrm{mg} / \mathrm{g})$, Allium cepa $(0.53$ $155 \mathrm{mg} / \mathrm{g})$, Boerhavia diffusa $(0.67 \mathrm{mg} / \mathrm{g})$, Osbeckia octandra $(0.79 \mathrm{mg} / \mathrm{g})$ and Bacopa monnieri $156(0.89 \mathrm{mg} / \mathrm{g})$.

157 Antioxidant activity of leafy vegetables were systematically assessed with reducing power 158 assay, lipid peroxidation assay, DPPH radical scavenging assay and total antioxidant capacity 159 assay and the results are shown in Table 2. The percent inhibition of DPPH radical due to leaf 160 extracts was in the ranged from 3.70 to $52.2 \%$. Among the leafy vegetables evaluated, Olax 161 zeylanica and Ipomoea batatas show higher DPPH radical scavenging activities compared with 162 other leaf extracts studied. Murraya koenigii Spreng, Hemidesmus indicus, Cassia auriculata and 163 Sesbania grandiflora extracts also show higher DPPH radical scavenging activity compared to 164 other leaves tested. However, Asteracantha longifolia, Alternathera sessilis, Amaranthus lividis, 165 Amaranthus caudatus and Syngonium angustatum displayed significantly lower DPPH radical 166 scavenging activity. 
167 Reducing power of the leaf extracts was within the range of $0.55-10.90 \mathrm{mg}$ ascorbic acid 168 equivalents (AAE/g dry weight of leaf) and Passiflora edulis (10.90 mg AAE/g dry weight) 169 showed significantly higher $(\mathrm{p}<0.05)$ reducing power compared with other leaves. Leaves of 170 Olax zeylanica and Allium cepa also have shown higher reducing properties. Boerhavia diffusa 171 (0.55 mg AAE/g dry weight), Triathema monogyna (0.59 mg AAE/g dry weight), Syngonium 172 angustatum (0.64 mg AAE/g dry weight), and Asteracantha longifolia (0.61 mg AAE/g dry 173 weight), showed lower reducing power comparatively.

174 Percentage inhibition of lipid peroxidation by leaf extracts were in the range from $34.3 \%$ 175 (Boerhavia diffusa) to 89.8\% (Asparagus racemosus). Polyscias scutellaria, Manihot esculenta, 176 Cucurbita maxima, Centella asiatica, Costus specious, Cardiospermum halicacabum, Murraya 177 Koenigii Spreng, Amaranthus spp., Leucas zeylanica and Solanum nigrum also showed higher 178 lipid peroxidation inhibition ability. Total antioxidant capacity of the leaf extracts were within 179 the range of $4.42-25.70 \mathrm{mg}$ AAE/g dry weight. Murraya Koenigii Spreng showed the highest 180 antioxidant capacity (25.70 mg AAE/g dry weight) followed by the Hemidesmus indicus (19.43 mg AAE/g dry weight) and Cassia auriculata (18.16 mg AAE/g dry weight). Other leafy 182 vegetables with relatively high antioxidant capacity were Passiflora edulis, Olax zeylanica and 183 Costus specious.

184 Figure 1 shows the regression analysis to correlate the four antioxidant assays with relevant to 185 total phenolic content of different leaf extracts. The highest correlation coefficient $\left(r^{2}=0.903\right)$ 186 was exhibited between the DPPH assay and the total pheolic content of leafy vegetable extracts 187 (Figure $1 \mathrm{~b}$ ), followed by antioxidant capacity assay and the total phenolic content $\left(\mathrm{r}^{2}=0.890\right)$ 188 (Figure 1a); reducing power assay and total phenolic $\left(\mathrm{r}^{2}=0.846\right)$ (Figure 1c) and between lipid 189 peroxidation and total phenolic content $\left(\mathrm{r}^{2}=0.769\right)$ (Figure 1d). As lower correlation values were 
observed in four antioxidant assays with reference to total carotene and chlorophyll contents, they are not summarizes here.

\subsection{Discussion}

The antioxidative potential of plant extracts can be measured using various in vitro assays and each assay is based on at least one feature of antioxidant activity. However, total antioxidant properties of plants cannot be evaluated by any single method because of their complex nature of phytochemicals (Chu et al., 2000). Therefore, two or more methods should always be employed in order to evaluate the total antioxidative effects of plant extracts such as green leafy vegetables. The present study showed remarkable variations in antioxidant activities among the green leafy vegetables studied. The leaves were analyzed in total phenolic, carotene and chlorophyll contents and in four different antioxidant assays, DPPH radical scavenging assay, reducing power assay, total antioxidant assay and lipid peroxidation assay.

Phenolics are one of the most important natural antioxidants because of their important bioactivities (Chandrasekara \& Shahidi, 2011). Phenolic substances have been reported for most of the examined leafy vegetables and Gymnema lactiferum, Sesbania grandiflora, Passiflora edulis, Murraya koenigii Spreng, Cassia auriculata and Hemidesmus indicus have shown higher phenolic content. Table 3 shows the major bioactives in some leafy vegetable extracts. In Sri Lanka these leafy vegetables, also use in medicinal formulations to control various chronic diseases. However, there is not much published research available on antioxidant properties of leaves of Gymnema lactiferum though it has higher phenolics compared with other leafy vegetables tested. Gymnema leaf posses' hypoglycemic properties (Bandara et al., 2009) and the antidiabetic components of this plant have been identified as gymnemic acid, a phenolic triterpene (Kanetkar et al., 2006; Surveswaran et al., 2007). Sesbania grandiflora, Passiflora 
214 edulis and Murraya koenigii Spreng are well known green leafy vegetables in Asia. Leaves of

215 Passiflora edulis, is a rich source of bioactive polyphenols and in a previous rat study, it was

216 mentioned that leaf extract could be an option to enhance the supply of antioxidants to safeguard

217 against oxidative stress (da Silva et al., 2013). Further, flavonoids present in Passiflora edulis

218 leaves were identified by a high-performance liquid chromatography-diode array detection-

219 tandem mass spectrometry method by Ferreres et al. (2007) and they have characterized sixteen

220 apigenin or luteolin derivatives such as vitexin, isovitexin, orientin and isoorientin. Major

221 antioxidant constituents of Cassia auriculata leaves are kaempferol-3-O-rutinoside together with

222 kaempferol, quercetin and luteolin (Juan-Badaturuge et al. (2011). Hemidesmus indicus is a

223 twining shrub and known to have wide pharmacological actions. 2-Hydroxy-4-methoxybenzoic

224 acid (HMBA) and a number of pregnane glycosides are believed to be responsible for its various

225 bioactivities and cinnamic acid, coumaric acid, gentisic acid and gallic acid are main phenolics

226 reported in this plant (Jayaram and Dharmesh, 2011). Major phenolics in Murraya koenigii

227 Spreng leaves are myricetin-3-galactoside, quercetin- $O$-pentohexoside, quercetin-3-diglucoside,

228 quercetin-3-O-rutinoside, quercetin-3-glucoside, quercetin-3-acetylhexoside, quercetin- $O$ -

229 xylopentoside, kaempferol-O-glucoside, and kaempferol-aglucoside (Singh et al., 2011).

230 Carotenoids are pigments which play a role in the protection of plants against photo-oxidative

231 processes and they are much effective antioxidant scavenging singlet molecular oxygen and

232 peroxyl radicals (Stahl \& Sies, 2003). Lutein is a major carotenoid in leafy vegetables which

233 showed marked antioxidant activities (Nicolle et al., 2004). Chandrika et al. (2010) have

234 quantified the carotenoid content in selected leafy vegetables. They have reported that leaves of

235 Ipomoea batatas showed the highest carotene content and Syngonium angustatum leaves

236 contained the highest amount of lutein as major cartenoid. In another study, carotenoid 
composition of green leafy vegetables was analyzed by HPLC and reported that Solanum nigrum were found to contain higher levels of both lutein and $\beta$-carotene in the range of 84-187 and 50$115 \mathrm{mg} / 100 \mathrm{~g}$ dry weight, respectively (Raju et al., 2007). In our study also we found that, leaves of Passiflora edulis, Cassia auriculata, Solanum nigrum also contain higher carotene contents and they may have higher singlet oxygen radical scavenging ability. However, in this study, we have not evaluated singlet oxygen radical scavenging assay for the leaf extracts.

Radical scavengers may protect cell tissues from free radicals, thereby preventing diseases such as cancer (Nakayama et al., 1993). The radical scavenging activity of methanolic extracts of leafy vegetables was tested using DPPH assay as this is a commonly employed method in antioxidant studies and offers a rapid technique in which to screen the radical scavenging activity of commodities (Amarowicz et al., 2004). In this process, polyphenolics have the ability to quench DPPH radicals by providing hydrogen atoms or by electron donation and convert them to a colorless product. Hence, higher the percentage of inhibition of free radical activity, the more potent the antioxidant activity of the extract in terms of hydrogen atom-donating capacity (Amarowicz, et al., 2004). The radical scavenging activity of leaf extracts of Olax zeylanica and Ipomea batatas was far superior to any of the other extracts investigated and this is the first reported results about DPPH radical scavenging ability of Olax zeylanica. Deng et al. (2013) also reported that leaves of Ipomea batatas showed good antioxidant activity though they have used different assays to evaluate antioxidant properties. Ipomoea batatas leaves are an excellent source of bioactive anthocyanin and polyphenolic constituents. The main anthocyanins reported in Ipomoea batatas leaves are acylated cyanidins and peonidins whereas major phenolic constituents were caffeic acid, 3-O-caffeoylquinic acid, 3,4-di- $O$-caffeoylquinic acid, 3,5-di- $O$ caffeoylquinic acid, 4,5-di-O-caffeoylquinic acid and 3,4,5-tri- $O$-caffeoylquinic acid and also 
260 these phenolics were positively correlate with radical scavenging activities of Ipomoea batatas

261 leaves (Islam et al., 2002).

262 Leaves of Murraya koengii, Cassia auriculata and Sesbania grandiflora also have shown higher

263 free radical scavenging activity and this may be due to presence of higher bioactive constituents.

264 Cassia auriculata is a medicinal plant widely used in traditional medicine for treating diabetes

265 and various other disease conditions and the methanolic extract of this leaf displayed potent

266 DPPH radical scavenging activity (Juan-Badaturuge et al., 2011). Other studies have shown that

267 oleoresin of Murraya koenigii Spreng extracted using acetone (Rao et al., 2007) and alcohol

268 (Ningappa et al., 2008) have reported to have higher radical-scavenging activities. Carbazole

269 alkaloids were identified as main bioactives in Murraya koenigii Spreng and it was suggested

270 that an arylhydroxy substituent on the carbazole rings plays a role in stabilizing the thermal

271 oxidation and rate of reaction against DPPH radical (Tachibana et al., 2003). Sesbania

272 grandiflora contains high levels of kaempferol and this may be the main contributor to the

273 antioxidant activitity (Andarwulan et al., 2012; Mustafa et al., 2010). Further, scavenging ability

274 toward DPPH is increased by the length of the effective conjugated double bonds of a compound

275 (Jiménez-Escrig et al., 2000). The major bioactives of Cassia auriculata leaves reported were

276 anthraquinone glycosides, terpenoid glycosides, protoanthocyanidin and phenolic acids and have

277 shown higher DPPH radical scavenging activities (Surveswaran et al., 2007). The extract of

278 Asteracantha longifolia, Alternathera sessilis, Amaranthus lividis, Amaranthus caudatus and

279 Syngonium angustatum contained lowest amount polyphenolics compared with other leaves.

280 Therefore, they exhibited lower radical scavenging activities. However, Alternanthera sessilis

281 plant extracts was studied for its antioxidant activity by Borah et al. (2011) and reported that

282 methonolic extract have shown highest radical scavenging activity. 
283 Reducing power is associated with antioxidant activity and they serve as a significant reflection 284 of the antioxidant property of a commodity (Oktay et al., 2003). Reducing power assay is also 285 widely used in evaluating antioxidant activity of plant polyphenols and the reducing power of 286 leaf extracts were evaluated by measuring the absorbance $700 \mathrm{~nm}$ after mixing the extracts with 287 ferric compounds. The samples with higher reducing power shows higher absorbance. The 288 presence of reductants like antioxidants in the leaf extracts causes the reduction of the $289 \mathrm{Fe}^{3+} /$ ferricyanide complex to the ferrous form indicating that they are electron donors and can 290 reduce the oxidized intermediates of lipid peroxidation process. Therefore, they can act as 291 primary and secondary antioxidants (Amarowicz et al., 2004). It was reported that the reducing 292 power of polyphenolics probably due to the presence of hydroxyl group which might act as 293 electron donors (Shamida et al., 1992). Leaves of Passiflora edulis and Olax zeylanica have 294 shown higher reducing potential. This could be attributed to the high phenolic content in these 295 leaf extracts, which can act as free radicals scavenger by donating an electron or hydrogen. In 296 our study, we found that the phenolic contents of leafy vegetables extracts, strongly correlate 297 with reducing power assay $\left(r^{2}=0.846\right)$.

298 Oxidation damages to the tissues through lipid peroxidation could result in changes in cellular 299 biomembranes (Skrzydlewska et al., 2002). We used three types of Amaranthus in the present 300 study: Amaranthus caudatus, Amaranthus lividis and Amaranthus viridis and they have shown 301 higher lipid peroxidation inhibition activity. Ozsoy and co-authors (2009) have reported that 302 Amaranth leaves contained naturally occurring antioxidant components and possessed 303 antioxidant activity which may be attributed to its lipid peroxidation inhibitory activities. 304 Isoqercetin and rutin were the most abundant flavonoids and salicylic acid, syringic acid, gallic 305 acid, vanilic acid, ferulic acid, p-coumaric acid and sinapic acid are the most common phenolic 
acids in amaranth cultivars (Khanam et al., 2013). Though Boerhaavia diffusa exhibited lower antioxidant properties compared with other leafy vegetables in this study, in a previous in vivo study, ethanolic extracts of Boerhaavia diffusa leaves have shown antioxidant and hepatoprotective properties such as inhibition of acetaminophen induced lipid peroxidation (Olaleye et al., 2010). Further, in another in vitro study, the antioxidant potency of methanolic extract of Boerhaavia diffusa and showed significant scavenging activity against hydroxyl and superoxide radicals and also it inhibited the lipid peroxidation in linoleic acid emulsion system

313 (Prathapan et al., 2011). Antioxidant properties of leaves of Hemidesmus indicus (L.) was evaluated by Murali et al. (2011) using an in vivo models (wister rats) and found that leaf of $H$. indicus var. pubescens possesses equipotent antioxidant effects with the standard antioxidant 316 drug, silymarin. Lipid peroxidation is the net result of any free radical attack on membrane and 317 other lipid constituent present in the system and this can be enzymatic or non-enzymatic. Since 318 we have used egg-yolk as a substrate for this assay, it could be suggested that leaf extracts are active against non-enzymatic oxidation and the inhibition of lipid peroxidation may be either due to chelation of Fe or by free radical trapping (Pandey et al, 2007). Lipid peroxidation inhibition

321 activity may be due to presence of polyphenolics and showed a good correlation with phenolic 322 contents of leaf $\left(r^{2}=0.769\right)$.

323 A spectrophotometric method described by Prieto et al. (1999) was used for the quantitative 324 determination of antioxidant capacity. This assay is based on the reduction of MO(VI) to MO(V) 325 by the sample analyte and subsequent formation of a green phosphate/MO(V) complex at acidic 326 medium. Measuring a total antioxidant capacity of a sample might by more useful than 327 determining that of specific antioxidant species in a sample. Total antioxidant capacity of leafy 328 vegetables such as Murraya koenigii Spreng, Hemidesmus indicus, Cassia auriculata, Passiflora 
329 edulis and Olax zeylanica and have shown higher antioxidant activities including higher reducing 330 potentials. In another study, Gupta and Prakash (2009) reported that antioxidant capacities were 331 in the order of Murraya koenigii> Amaranthus sp.> Centella asiatica, and they have expressed 332 the antioxidant capacities as equivalents of ascorbic acid in $\mu \mathrm{mol} / \mathrm{g}$ of sample. A similar trend is 333 also observed in our findings for the antioxidant capacity of these three leaves. The total 334 antioxidant capacity of leaf extracts may be attributed to their chemical composition and 335 phenolic content. In our study, we found that the phenolic contents of leafy vegetables extracts, 336 strongly correlate with total antioxidant capacity assay $\left(\mathrm{r}^{2}=0.890\right)$. A good correlation between 337 phenolics and antioxidant properties has also been previously reported by Zheng and Wang 338 (2001) and Rudnicki et al. (2007). However, a comparatively poor correlation was found between 339 chlorophyll and carotene content of studied leafy vegetables and antioxidant assays used (data 340 not shown).

341 In conclusion, the data from this screening study indicated that these leafy vegetables have 342 shown remarkable variations in antioxidant activities. Among the leafy vegetables studied, 343 Sesbania grandiflora, Cassia auriculata, Murraya koenigii Spreng, Passiflora edulis, Gymnema 344 lactiferum and Olax zeylanica showed comparatively higher antioxidant properties. A good 345 correlation between the results from total polyphenolics and the four antioxidative assays of 346 leafy vegetables were observed in this study.

\section{Acknowledgement}

We greatly acknowledge the financial support provided by National Science Foundation of Sri Lanka (NSF) (Research Grant \# RG/AG/2014/04)

\section{References}


Amarowicz, R., Pegg, R. B., Rahimi-Moghaddam, P., Barl, B., \& Weil, J. A. (2004). Freeradical scavenging capacity and antioxidant activity of selected plant species from the Canadian prairies. Food Chemistry, 84(4), 551-562.

Andarwulan, N., Kurniasih, D., Apriady, R. A., Rahmat, H., Roto, A. V., \& Bolling, B. W. (2012). Polyphenols, carotenoids, and ascorbic acid in underutilized medicinal vegetables. Journal of Functional Foods, 4(1), 339-347.

Bandara, T., Rokeya, B., Khan, S., Ali, L., Ekanayake, S., Jansz, E.R. and Balasubramanium, K. (2009). Effects of Gymnema lactiferum leaves on glycemic and lipidemic status in type 2 diabetes subjects. Bangladesh Journal of Pharmacology, 4(2), 92-95.

Borah, A., Yadav, R. N. S., \& Unni, B. G. (2011). In vitro antioxidant and free radical scavenging activity of Alternanthera sessilis. International Journal of Pharmaceutical Sciences and Research. (2(6), 1502-1506.

Chandrasekara, A. and Shahidi, F., (2011). Determination of antioxidant activity in free and hydrolyzed fractions of millet grains and characterization of their phenolic profiles by HPLCDAD-ESI-MS n. Journal of Functional Foods, 3(3), pp.144-158.

Chandrika, U. G., Basnayake, B. M. L. B., Athukorala, I., Colombagama, P. W. N. M., \& Goonetilleke, A. (2010). Carotenoid content and in vitro bioaccessibility of lutein in some leafy vegetables popular in Sri Lanka. Journal of Nutritional Science and Vitaminology, 56(3), 203207.

Chu, Y. H., Chang, C. L., \& Hsu, H. F. (2000). Flavonoid content of several vegetables and their antioxidant activity. Journal of the Science of Food and Agriculture, 80(5), 561-566.

da Silva, J.K., Cazarin, C.B.B., Colomeu, T.C., Batista, Â.G., Meletti, L.M., Paschoal, J.A.R., Júnior, S.B., Furlan, M.F., Reyes, F.G.R., Augusto, F. and Júnior, M.R.M. (2013). Antioxidant activity of aqueous extract of passion fruit (Passiflora edulis) leaves: in vitro and in vivo study. Food Research International, 53(2).882-890.

Deng, G. F., Lin, X., Xu, X. R., Gao, L. L., Xie, J. F., \& Li, H. B. (2013). Antioxidant capacities and total phenolic contents of 56 vegetables. Journal of Functional Foods, 5(1), 260-266.

Ferreres, F., Sousa, C., Valentão, P., Andrade, P. B., Seabra, R. M., \& Gil-Izquierdo, Á. (2007). New C-deoxyhexosyl flavones and antioxidant properties of Passiflora edulis leaf extract. Journal of Agricultural and Food Chemistry, 55(25), 10187-10193.

Gunathilake, K.D.P.P., \& Rupasinghe, H.P.V. (2014). Inhibition of Human Low-Density Lipoprotein Oxidation in vitro by Ginger Extracts. Journal of Medicinal Food 17(4), 424-431.

Gupta, S. and Prakash, J., (2009). Studies on Indian green leafy vegetables for their antioxidant activity. Plant Foods for Human Nutrition, 64(1), pp.39-45. 
Hatano T, Kagawa H, Yasuhara T \& Okuda T. (1988). Two new flavonoids and other constituents in liquorice root : their relative astringency and radical scavenging effects. Chemical and Pharmaceutical Bulletin, 36, 1090-2097.

Houston, M. C. (2010). The role cellular micronutrient analysis, nutraceuticals, vitamins and antioxidants and minerals in the prevention and treatment of hypertension and cardiovascular disease. Therapeutic Advances in Cardiovascular Disease, 4(3), 165-183.

Islam, S., Yoshimoto, M., Ishiguro, K. and Yamakawa, O. (2002). Bioactive compounds in Ipomoea batatas leaves. In XXVI International Horticultural Congress: Issues and Advances in Postharvest Horticulture 628, 693-699.

Jayaram, S. \& Dharmesh, S.M., (2011). Assessment of antioxidant potentials of free and bound phenolics of Hemidesmus indicus (L) $\mathrm{R}$. $\mathrm{Br}$ against oxidative damage. Pharmacognosy research, 3(4), 225.

Jiménez-Escrig, A., Jiménez-Jiménez, I., Sánchez-Moreno, C. and Saura-Calixto, F. (2000). Evaluation of free radical scavenging of dietary carotenoids by the stable radical 2, 2-diphenyl-1-picrylhydrazyl. Journal of the Science of Food and Agriculture, 80(11), 1686-1690.

Juan-Badaturuge, M., Habtemariam, S., \& Thomas, M. J. (2011). Antioxidant compounds from a South Asian beverage and medicinal plant, Cassia auriculata. Food Chemistry, 125(1), 221-225.

Kadiragamanathar, S. Geethika, C.D.H., Premakumara, G.A.S, Balasubramanium, K. and Sotheeswaran, S. (2009). Quantification of Gymnemic acid content of Sri Lankan Gymnema species. Chemistry in Sri Lanka, 26(2), 22.

Kaliora, A. C., Dedoussis, G. V. Z., \& Schmidt, H. (2006). Dietary antioxidants in preventing atherogenesis-A review. Journal of Atherosclerosis, 187, 1-17.

Kanetkar, P.V., Singhal, R.S., Laddha, K.S. and Kamat, M.Y. (2006). Extraction and quantification of gymnemic acids through gymnemagenin from callus cultures of Gymnema sylvestre. Phytochemical Analysis, 17(6), 409-413.

Kesari, A. N., Gupta, R. K., \& Watal, G. (2005). Hypoglycemic effects of Murraya koenigii on normal and alloxan-diabetic rabbits. Journal of Ethnopharmacology, 97, 247-251.

Khanam, U.K.S., Oba, S., Yanase, E. and Murakami, Y. (2012). Phenolic acids, flavonoids and total antioxidant capacity of selected leafy vegetables. Journal of Functional Foods, 4(4), 979987.

Khanam, U.K.S. and Oba, S. (2013). Bioactive substances in leaves of two amaranth species, Amaranthus tricolor and A. hypochondriacus. Canadian Journal of Plant Science, 93(1), 47-58. 
Kichtenthaler, H.K., Wellburn, A.R. (1983). Determination of Total Carotenoids and Chlorophylls A and B of Leaf in Different Solvents. Biochemical Society Transactions, 11. 591592.

Kubo, I., Fijita, K., Kubo, A., Nehei, K., \& Gura, T. (2004). Antibacterial activity of coriander volatile compounds against Salmonella choleraesuis. Journal of Agricultural and Food Chemistry, 52, 3329-3332.

Madamanchi N.R., Vendrov A., Runge M.S. (2005). Oxidative stress and vascular disease. Arteriosclerosis Thrombosis and Vascular Biology. 25, 29-38.

Murali, A., Ashok, P., \& Madhavan, V. (2011). Antioxidant activity of leaf of Hemidesmus indicus (L.) R. Br. var. pubescens (WA) Hk. f. (Periplocaceae)-an in vivo analysis. Spatula DDPeer Reviewed Journal on Complementary Medicine and Drug Discovery, 1(2), 91-100.

Mustafa, R.A., Hamid, A.A., Mohamed, S. and Bakar, F.A. (2010). Total phenolic compounds, flavonoids, and radical scavenging activity of 21 selected tropical plants. Journal of Food Science, 75(1), 28-35.

Nakayama, T., Yamada, M., Osawa, T., \& Kawakishi, S. (1993). Suppression of active oxygeninduced cytotoxicity by flavonoids. Biochemical Pharmacology, 45, 265-267.

Nicolle, C., Carnat, A., Fraisse, D., Lamaison, J.L., Rock, E., Michel, H., Amouroux, P. and Remesy, C. (2004). Characterisation and variation of antioxidant micronutrients in lettuce (Lactuca sativa folium). Journal of the Science of Food and Agriculture, 84(15), 2061-2069.

Ningappa, M. B., Dinesha, R., \& Srinivas, L. (2008). Antioxidant and free radical scavenging activities of polyphenol-enriched curry leaf (Murraya koenigii L.) extracts. Food Chemistry, 106(2), 720-728.

Ohkowa, M., Ohisi, N., \& Yagi, K. (1979). Assay for lipid peroxides in animal tissue by thiobarbituric acid reaction. Analytical Biochemistry, 95, 351-358.

Oktay, M., Gülçin, İ., \& Küfrevioğlu, Ö. İ. (2003). Determination of in vitro antioxidant activity of fennel (Foeniculum vulgare) seed extracts. LWT-Food Science and Technology, 36(2), 263271.

Olaleye, M. T., Akinmoladun, A. C., Ogunboye, A. A., \& Akindahunsi, A. A. (2010). Antioxidant activity and hepatoprotective property of leaf extracts of Boerhaavia diffusa Linn against acetaminophen-induced liver damage in rats. Food and Chemical Toxicology, 48(8), 2200-2205.

Oyaizu, M., (1986). Studies on products of browning reaction prepared from glucosamine. Japanese Journal of Nutrition. 44, 307-315. 
Ozsoy, N., Yilmaz, T., Kurt, O., Can, A. and Yanardag, R. (2009). In vitro antioxidant activity of Amaranthus lividus L. Food Chemistry, 116(4), 867-872.

Pandey, N., Chaurasia, J. K., Tiwari, O.P. and Tripathi, Y.B., (2007). Antioxidant properties of different fractions of tubers from Pueraria tuberosa Linn. Food Chemistry, 105(1), pp.219-222.

Prathapan, A., Singh, M. K., Anusree, S. S., Kumar, D. S., Sundaresan, A., \& Raghu, K. G. (2011). Antiperoxidative, free radical scavenging and metal chelating activities of Boerhaavia diffusa L. Journal of Food Biochemistry, 35(5), 1548-1554.

Prieto, P., Pineda, M., \& Aguilar, M. (1999). Spectrophotometric quantitation of antioxidant capacity through the formation of a phosphomolybdenum complex: specific application to the determination of vitamin E. Analytical Biochemistry, 269, 337-341.

Rajesh Kumar, N. V., Joy, K. L., Kuttan, G., Ramsewak, R. S., Nair, M. G., \& Kuttan, R. (2002). Antitumour and anticarcinogenic activity of Phyllanthus amarus extract. Journal of Ethnopharmacology, 81, 17-22.

Raju, M., Varakumar, S., Lakshminarayana, R., Krishnakantha, T. P., \& Baskaran, V. (2007). Carotenoid composition and vitamin A activity of medicinally important green leafy vegetables. Food Chemistry, 101(4), 1598-1605.

Rao, G.N., Kumar, P.M., Dhandapani, V.S., Krishna, T.R. and Hayashi, T., 2000. Constituents of Cassia auriculata. Fitoterapia, 71(1), 82-83.

Rao, L. J. M., Ramalakshmi, K., Borse, B. B., \& Raghavan, B. (2007). Antioxidant and radicalscavenging carbazole alkaloids from the oleoresin of curry leaf (Murraya koenigii Spreng.). Food Chemistry, 100(2), 742-747.

Rudnicki, M., de Oliveira, M. R., da Veiga Pereira, T., Reginatto, F. H., Dal-Pizzol, F., \& Moreira, J. C. F. (2007). Antioxidant and antiglycation properties of Passiflora alata and Passiflora edulis extracts. Food Chemistry, 100(2), 719-724.

Stahl, W. \& Sies, H. (2003). Antioxidant activity of catotenoids. Molecular Aspects of Medicine, $24,345-351$.

Shimada, K., Fujikawa, K., Yahara, K. and Nakamura, T., (1992). Antioxidative properties of xanthan on the autoxidation of soybean oil in cyclodextrin emulsion. Journal of Agricultural and Food Chemistry, 40(6), pp.945-948.

Singh, A.P., Wilson, T., Luthria, D., Freeman, M.R., Scott, R.M., Bilenker, D., Shah, S., Somasundaram, S. and Vorsa, N., (2011). LC-MS-MS characterisation of curry leaf flavonols and antioxidant activity. Food Chemistry, 127(1), 80-85. 
Singleton, V. L., Orthofer, R., \& Lamuela-Raventos, R. (1999). Analysis of total phenols and other oxidation substrates and antioxidants by means of FC reagent. Methods in Enzymology, 29, $152-178$.

Skrzydlewska, E., Ostrowska, J., Farbiszewski, R., \& Michalak, K. (2002). Protective effect of green tea against lipid peroxidation in the rat liver, blood serum and the brain. Phytomedicine, 9(3), 232-238.

Subhasree, B., Baskar, R., Keerthana, R. L., Susan, R. L., \& Rajasekaran, P. (2009). Evaluation of antioxidant potential in selected green leafy vegetables. Food Chemistry, 115(4), 1213-1220.

Surveswaran, S., Cai, Y.Z., Corke, H. and Sun, M. (2007). Systematic evaluation of natural phenolic antioxidants from 133 Indian medicinal plants. Food Chemistry, 102(3), 938-953.

Tachibana, Y., Kikuzaki, H., Lajis, N.H. and Nakatani, N. (2003). Comparison of antioxidative properties of carbazole alkaloids from Murraya koenigii leaves. Journal of Agricultural and Food Chemistry, 51(22), 6461-6467.

Türlerinde, F. Ç. K. B. A., Klorofil-A, B., \& Saptanması, İ. S. (1998). Spectrophotometric determination of chlorophyll-A, B and total carotenoid contents of some algae species using different solvents. Turkish Journal of Botany, 22, 13-17.

Zheng, W., \& Wang, S. Y. (2001). Antioxidant activity and phenolic compounds in selected herbs. Journal of Agricultural and Food Chemistry, 49(11), 5165-5170.

Zhang, M., Hettiarachchy, N.S., Horax, R., Kannan, A., Praisoody, A. and Muhundan, A. (2011). Phytochemicals, antioxidant and antimicrobial activity of Hibiscus sabdariffa, Centella asiatica, Moringa oleifera and Murraya koenigii leaves. Journal of Medicinal Plants Research, 5(30), 6672-6680. 

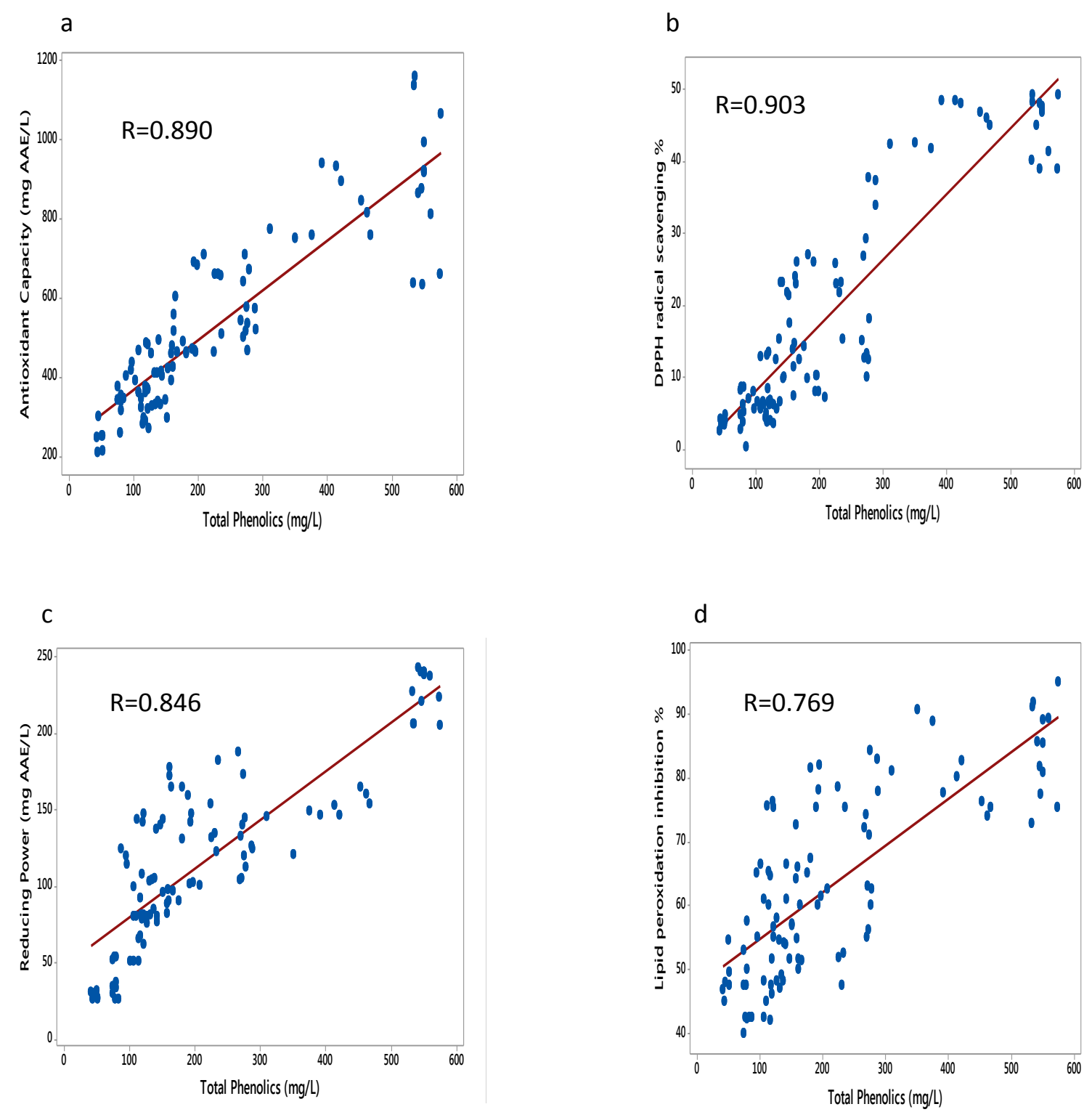

Figure 1. Correlation between total phenolics and four antioxidant activities; antioxidant capacity (a), DPPH radical scavenging activity (b), reducing power (c), lipid peroxidation assay (d) 
Table 1. Total phenolic, chlorophyll and carotene content of selected green leafy vegetables in Sri Lanka

\begin{tabular}{|c|c|c|c|c|}
\hline Common names & Scientific name & $\begin{array}{c}\text { Total } \\
\text { Phenolic (mg } \\
\text { GAE/g dw) }\end{array}$ & $\begin{array}{c}\text { Total } \\
\text { Chlorophy } \\
\text { ll }(\mathbf{a}+\mathbf{b}) \\
(\mu \mathrm{g} / \mathbf{g ~ d w})\end{array}$ & $\begin{array}{c}\text { Total } \\
\text { Carotene } \\
(\mathbf{m g} / \mathrm{g} \mathrm{dw})\end{array}$ \\
\hline Koppa kola/shield aralia & Polyscias scutellaria & $3.19 \pm 0.15$ & $21.03 \pm 0.21$ & $1.99 \pm 0.01$ \\
\hline Kurignan/ceylon cow tree & Gymnema lactiferum & $11.03 \pm 0.42$ & $23.03 \pm 1.22$ & $1.77 \pm 0.09$ \\
\hline Wel kohila/five fingers & Syngonium angustatum & $2.65 \pm 0.10$ & $31.01 \pm 1.22$ & $3.13 \pm 0.04$ \\
\hline Pitasudu sarana/spreading hogweed & Boerhavia diffusa & $1.59 \pm 0.92$ & $9.27 \pm 1.06$ & $0.67 \pm 0.02$ \\
\hline Cassava & Manihot esculenta & $2.94 \pm 0.11$ & $26.06 \pm 3.23$ & $2.19 \pm 0.01$ \\
\hline Sarana/giant pigweed & Triathema monogyna & $2.96 \pm 0.18$ & $27.06 \pm 5.03$ & $1.49 \pm 0.02$ \\
\hline Nivithi/spinach & Spinaces oleracea & $3.81 \pm 0.16$ & $14.05 \pm 0.23$ & $1.96 \pm 0.02$ \\
\hline Thampala & Amaranthus caudatus & $1.56 \pm 0.61$ & $12.04 \pm 2.42$ & $1.18 \pm 0.05$ \\
\hline Pumpkin & Cucurbita maxima & $2.70 \pm 0.07$ & $20.06 \pm 2.04$ & $2.05 \pm 0.01$ \\
\hline Sweet potato & Ipomoea batatas & $5.68 \pm 0.13$ & $27.06 \pm 1.05$ & $2.26 \pm 0.04$ \\
\hline Kathurumurunga & Sesbania grandiflora & $10.98 \pm 0.19$ & $26.20 \pm 1.16$ & $2.29 \pm 0.01$ \\
\hline Mukunuwenna/joyweed & Alternathera sessilis & $0.98 \pm 0.08$ & $10.03 \pm 6.16$ & $0.47 \pm 0.02$ \\
\hline Gotukola & Centella asiatica & $1.55 \pm 0.05$ & $25.32 \pm 1.04$ & $2.16 \pm 0.08$ \\
\hline Passion fruit & Passiflora edulis & $9.21 \pm 0.14$ & $33.01 \pm 3.04$ & $4.17 \pm 0.01$ \\
\hline Hathawariya/wild asparagus & Asparagus racemosus & $1.47 \pm 0.09$ & $24.00 \pm 4.27$ & $1.98 \pm 0.01$ \\
\hline Kankung/water spinach & Ipoтоеа аquatica & $2.46 \pm 0.08$ & $25.01 \pm 5.30$ & $2.11 \pm 0.02$ \\
\hline Heen bowitiya & Osbeckia octandra & $5.18 \pm 0.41$ & $13.02 \pm 4.00$ & $0.79 \pm 0.01$ \\
\hline Thebu/spiral ginger & Costus specious & $4.60 \pm 0.08$ & $17.02 \pm 4.00$ & $1.89 \pm 0.02$ \\
\hline Ranawara & Cassia auriculata & $10.70 \pm 0.12$ & $27.25 \pm 7.07$ & $3.46 \pm 0.03$ \\
\hline Wel penela/balloon vine & Cardiospermum halicacabum & $2.16 \pm 0.46$ & $12.13 \pm 2.07$ & $1.28 \pm 0.01$ \\
\hline Neeramulliya & Asteracantha longifolia $L$ & $0.92 \pm 0.08$ & $37.12 \pm 4.21$ & $2.78 \pm 0.02$ \\
\hline Karapincha/curry leaves & Murraya Koenigii spreng & $8.71 \pm 0.02$ & $27.05 \pm 4.02$ & $1.99 \pm 0.00$ \\
\hline Koora thampala/slender amaranth & Amaranthus viridis & $3.25 \pm 0.03$ & $19.08 \pm 6.02$ & $1.91 \pm 0.00$ \\
\hline Rathu thampala/wild amaranth & Amaranthus lividis & $2.37 \pm 0.07$ & $15.09 \pm 2.02$ & $1.23 \pm 0.03$ \\
\hline Anguna/green milkweed climber & Watakaka volubilis & $5.47 \pm 0.07$ & $24.04 \pm 0.02$ & $2.34 \pm 0.01$ \\
\hline Thumba & Leucas zeylanica & $3.29 \pm 0.19$ & $15.04 \pm 6.01$ & $1.10 \pm 0.01$ \\
\hline Onion leaves/spring onion & Allium сера & $3.99 \pm 0.16$ & $10.01 \pm 2.11$ & $0.53 \pm 0.01$ \\
\hline Kowakka kola/Ivy gourd & Coccinia grandis & $2.29 \pm 0.13$ & $14.01 \pm 0.22$ & $1.64 \pm 0.02$ \\
\hline Asamodagam & Trachyspermum involucratum & $2.24 \pm 0.11$ & $11.02 \pm 0.12$ & $1.01 \pm 0.01$ \\
\hline Lunuwila/water hyssop & Bacopa monnieri & $5.47 \pm 0.09$ & $15.06 \pm 2.33$ & $0.89 \pm 0.01$ \\
\hline Kalukamberiya/black night shade & Solanum nigram & $3.97 \pm 0.45$ & $27.14 \pm 0.13$ & $3.18 \pm 0.01$ \\
\hline Polpala/mountain knot grass & Aerva lanata & $2.15 \pm 0.12$ & $11.05 \pm 0.27$ & $1.17 \pm 0.04$ \\
\hline Mella kola & Olax zeylanica & $6.91 \pm 0.64$ & $22.14 \pm 3.07$ & $2.15 \pm 0.04$ \\
\hline Iramusu & Hemidesmus indicus & $8.18 \pm 0.31$ & $25.02 \pm 9.35$ & $2.61 \pm 0.01$ \\
\hline
\end{tabular}

Values are presented as mean $\pm \mathrm{SD}, \mathrm{n}=3$.

* mg gallic acid equivalent per $g$ dry weight $(\mathrm{dw})$ leaves 
Table 2. DPPH radical scavenging activity, reducing power, lipid peroxidation activity and total antioxidant capacity of selected green leafy vegetables in Sri Lanka

\begin{tabular}{|c|c|c|c|c|c|}
\hline Common name & Scientific name & $\begin{array}{c}\text { DPPH } \\
\text { radical } \\
\text { scavenging } \\
\text { activity (\% } \\
\text { inhibition) } \\
\end{array}$ & $\begin{array}{c}\text { Reducing } \\
\text { power assay } \\
\text { (mg AAE/g } \\
\text { dw)* }\end{array}$ & $\begin{array}{l}\% \text { inhibition } \\
\text { of lipid } \\
\text { peroxidation }\end{array}$ & $\begin{array}{c}\text { Total } \\
\text { antioxidant } \\
\text { capacity (mg } \\
\text { AAE/g dw)* }\end{array}$ \\
\hline Koppa kola & Polyscias scutellaria & $13.71 \pm 3.21$ & $1.93 \pm 0.02$ & $81.51 \pm 5.10$ & $11.70 \pm 0.71$ \\
\hline Kurignan & Gymnema lactiferum & $14.22 \pm 0.11$ & $4.47 \pm 0.07$ & $73.92 \pm 10.41$ & $12.62 \pm 0.47$ \\
\hline Wel kohila & Syngonium angustatum & $5.21 \pm 1.62$ & $0.64 \pm 0.04$ & $55.66 \pm 9.11$ & $6.62 \pm 0.12$ \\
\hline Pitasudu sarana & Boerhavia diffusa & $4.74 \pm 0.28$ & $0.55 \pm 0.04$ & $34.37 \pm 1.71$ & $6.28 \pm 0.10$ \\
\hline Cassava & Manihot esculenta & $22.02 \pm 0.90$ & $3.79 \pm 0.06$ & $81.77 \pm 5.46$ & $4.42 \pm 0.46$ \\
\hline Sarana & Triathema monogyna & $9.01 \pm 1.21$ & $0.59 \pm 0.06$ & $70.78 \pm 6.75$ & $7.02 \pm 0.26$ \\
\hline Nivithi & Spinaces oleracea & $10.01 \pm 0.21$ & $1.79 \pm 0.16$ & $56.71 \pm 4.89$ & $7.24 \pm 0.06$ \\
\hline Thampala & Amaranthus caudatus & $4.53 \pm 0.80$ & $0.70 \pm 0.04$ & $79.21 \pm 1.78$ & $6.92 \pm 0.06$ \\
\hline Pumpkin & Cucurbita maxima & $16.95 \pm 5.53$ & $2.08 \pm 0.01$ & $87.72 \pm 1.48$ & $12.72 \pm 0.13$ \\
\hline Sweet potato & Ipomoea batatas & $51.29 \pm 2.22$ & $1.46 \pm 0.07$ & $59.12 \pm 7.65$ & $10.36 \pm 0.10$ \\
\hline Kathurumurunga & Sesbania grandiflora & $44.78 \pm 3.32$ & $3.79 \pm 0.04$ & $81.56 \pm 2.80$ & $10.98 \pm 0.20$ \\
\hline Mukunuwenna & Alternathera sessilis & $4.37 \pm 0.51$ & $0.92 \pm 0.02$ & $71.36 \pm 3.46$ & $4.44 \pm 0.14$ \\
\hline Gotukola & Centella asiatica & $8.42 \pm 0.33$ & $1.06 \pm 0.02$ & $80.34 \pm 7.23$ & $6.76 \pm 0.03$ \\
\hline Passion fruit & Passiflora edulis & $45.91 \pm 0.85$ & $10.90 \pm 0.10$ & $75.25 \pm 5.33$ & $16.08 \pm 0.04$ \\
\hline Hathawariya & Asparagus racemosus & $6.81 \pm 1.13$ & $1.38 \pm 0.10$ & $89.81 \pm 2.53$ & $6.66 \pm 0.07$ \\
\hline Kankung & Ipoтоеа аquatica & $6.40 \pm 0.28$ & $1.57 \pm 0.06$ & $52.82 \pm 6.00$ & $9.46 \pm 0.29$ \\
\hline Heen bowitiya & Osbeckia octandra & $13.43 \pm 3.04$ & $4.61 \pm 0.14$ & $73.93 \pm 12.00$ & $6.84 \pm 0.16$ \\
\hline Thebu & Costus specious & $22.51 \pm 0.87$ & $2.58 \pm 0.12$ & $80.94 \pm 7.80$ & $14.46 \pm 0.12$ \\
\hline Ranawara & Cassia auriculata & $47.21 \pm 0.49$ & $4.78 \pm 0.02$ & $37.02 \pm 7.18$ & $18.16 \pm 0.18$ \\
\hline Wel penela & Cardiospermum halicacabum & $6.29 \pm 0.30$ & $5.18 \pm 0.30$ & $86.72 \pm 4.37$ & $6.68 \pm 0.05$ \\
\hline Neeramulliya & Asteracantha longifolia $L$ & $3.71 \pm 0.33$ & $0.61 \pm 0.02$ & $74.81 \pm 5.94$ & $5.28 \pm 0.18$ \\
\hline Karapincha & Murraya Koenigii spreng & $48.80 \pm 0.67$ & $2.11 \pm 0.01$ & $83.52 \pm 4.72$ & $25.70 \pm 0.37$ \\
\hline Koora thampala & Amaranthus viridis & $24.30 \pm 1.55$ & $4.40 \pm 0.12$ & $84.48 \pm 6.32$ & $15.82 \pm 0.36$ \\
\hline Rathu thampala & Amaranthus lividis & $4.25 \pm 3.20$ & $1.29 \pm 0.04$ & $84.19 \pm 10.93$ & $5.67 \pm 0.29$ \\
\hline Anguna & Watakaka volubilis & $12.73 \pm 0.60$ & $1.78 \pm 0.12$ & $64.10 \pm 22.54$ & $10.33 \pm 0.34$ \\
\hline Thumba & Leucas zeylanica & $14.36 \pm 0.41$ & $1.79 \pm 0.02$ & $83.30 \pm 9.94$ & $9.12 \pm 0.17$ \\
\hline Onion leaves & Allium сера & $7.71 \pm 0.51$ & $5.42 \pm 0.02$ & $75.54 \pm 13.75$ & $14.52 \pm 0.11$ \\
\hline Kowakka kola & Coccinia grandis & $13.21 \pm 0.38$ & $1.99 \pm 0.15$ & $71.43 \pm 5.17$ & $7.24 \pm 0.12$ \\
\hline Asamodagam & Trachyspermum involucratum & $6.80 \pm 1.35$ & $1.60 \pm 0.01$ & $79.62 \pm 9.60$ & $7.16 \pm 0.31$ \\
\hline Lunuwila & Bacopa monnieri & $24.57 \pm 5.24$ & $2.14 \pm 0.09$ & $25.71 \pm 14.41$ & $15.46 \pm 0.07$ \\
\hline Kalukamberiya & Solanum nigram & $26.21 \pm 0.73$ & $3.98 \pm 0.09$ & $84.41 \pm 5.31$ & $8.59 \pm 0.12$ \\
\hline Polpala & Aerva lanata & $5.51 \pm 1.12$ & $1.02 \pm 0.04$ & $65.01 \pm 6.42$ & $7.54 \pm 0.17$ \\
\hline Mella kola & Olax zeylanica & $52.25 \pm 0.56$ & $5.76 \pm 0.31$ & $70.69 \pm 11.22$ & $15.86 \pm 0.11$ \\
\hline Iramusu & Hemidesmus indicus & $48.34 \pm 0.34$ & $4.97 \pm 0.08$ & $55.63 \pm 5.66$ & $19.43 \pm 0.75$ \\
\hline
\end{tabular}

Values are presented as mean $\pm \mathrm{SD}, \mathrm{n}=3$.

* mg Ascorbic acid equivalent per g dry weight leaves 
Table 3: major bioactive content in selected leafy vegetables

\begin{tabular}{|c|c|c|c|}
\hline Bioactives & Leafy vegetables & $\begin{array}{l}\text { Content in } \\
\text { mg/g dry } \\
\text { weight }\end{array}$ & References \\
\hline Gymnemic acid & Gymnema lactiferum & $10-54$ & Kadiragamanathar et al., 2009 \\
\hline $\begin{array}{l}\text { 2-Hydroxy-4-methoxybenzoic acid } \\
\text { Gentisic acid }\end{array}$ & Hemidesmus indicus & $\begin{array}{l}0.10 \\
1.35\end{array}$ & Jayaram and Dharmesh, 2011 \\
\hline Ferulic acid & $\begin{array}{l}\text { Hemidesmus indicus } \\
\text { Amaranthus tricolor }\end{array}$ & $\begin{array}{l}0.25 \\
0.003^{*}\end{array}$ & $\begin{array}{l}\text { Jayaram and Dharmesh, } 2011 \\
\text { Khanam et al., } 2013\end{array}$ \\
\hline Caffeic acid & $\begin{array}{l}\text { Hemidesmus indicus } \\
\text { Ipomoea batatas }\end{array}$ & $\begin{array}{l}0.12 \\
2.17\end{array}$ & $\begin{array}{l}\text { Jayaram and Dharmesh, } 2011 \\
\text { Islam et al., } 2002\end{array}$ \\
\hline Kaempferol-3- $O$-rutinoside & Cassia auriculata & Not given & Juan-Badaturuge et al., 2011 \\
\hline $\begin{array}{l}\text { myricetin-3-galactoside } \\
\text { quercetin- } O \text {-pentohexoside } \\
\text { quercetin-3-diglucoside } \\
\text { quercetin- } O \text {-xylopentoside } \\
\text { kaempferol- } O \text {-glucoside }\end{array}$ & Murraya koenigii Spreng & $\begin{array}{l}0.33 \\
0.71 \\
0.06 \\
0.70 \\
2.41\end{array}$ & Singh et al., 2011 \\
\hline \multirow[t]{2}{*}{ quercetin-3-glucoside } & Murraya koenigii Spreng & 1.44 & Singh et al., 2011 \\
\hline & Cassia auriculata & $0.31^{*}$ & Rao et al., 2000 \\
\hline \multirow[t]{2}{*}{ Lutein } & $\begin{array}{l}\text { Polyscias scutellaria } \\
\text { Gymnema lactiferum } \\
\text { Syngonium angustatum } \\
\text { Manihot esculenta } \\
\text { Triathema monogyna } \\
\text { Spinaces oleracea } \\
\text { Amaranthus caudatus } \\
\text { Cucurbita maxima } \\
\text { Ipomoea batatas } \\
\text { Sesbania grandiflora } \\
\text { Alternathera sessilis } \\
\text { Centella asiatica }\end{array}$ & $\begin{array}{l}0.89 \\
0.93 \\
1.73 \\
1.66 \\
0.76 \\
0.64 \\
0.49 \\
1.53 \\
1.69 \\
1.08 \\
0.29 \\
0.98\end{array}$ & Chandrika et al., 2010 \\
\hline & Murraya koenigii Spreng & 0.33 & Zhang et al., 2011 \\
\hline \multirow[t]{2}{*}{$\beta$-carotene } & $\begin{array}{l}\text { Polyscias scutellaria } \\
\text { Gymnema lactiferum } \\
\text { Syngonium angustatum } \\
\text { Manihot esculenta } \\
\text { Triathema monogyna } \\
\text { Spinaces oleracea } \\
\text { Amaranthus caudatus } \\
\text { Cucurbita maxima } \\
\text { Ipomoea batatas } \\
\text { Sesbania grandiflora } \\
\text { Alternathera sessilis } \\
\text { Centella asiatica }\end{array}$ & $\begin{array}{l}0.17 \\
1.63 \\
0.26 \\
0.52 \\
0.56 \\
0.30 \\
0.40 \\
0.66 \\
0.74 \\
0.40 \\
0.28 \\
0.26 \\
\end{array}$ & Chandrika et al., 2010 \\
\hline & Murraya koenigii Spreng & 0.11 & Zhang et al., 2011 \\
\hline acylated cyanidins and peonidins & Ipomoea batatas & Not given & Islam et al., 2002 \\
\hline $\begin{array}{l}\text { 3-O-caffeoylquinic acid } \\
\text { 3,4-di- } O \text {-caffeoylquinic acid } \\
\text { 3,5-di- } O \text {-caffeoylquinic acid } \\
\text { 4,5-di- } O \text {-caffeoylquinic acid }\end{array}$ & Ipomoea batatas & Not given & Islam et al., 2002 \\
\hline
\end{tabular}




\begin{tabular}{|c|c|c|c|}
\hline 3,4,5-tri- $O$-caffeoylquinic acid & & & \\
\hline Carbazole alkaloids & Murraya koenigii Spreng & & Tachibana et al., 2003 \\
\hline Quercetin & $\begin{array}{l}\text { Sesbania grandiflora } \\
\text { Cassia auriculata }\end{array}$ & $\begin{array}{l}0.03^{*} \\
\text { Not given }\end{array}$ & $\begin{array}{l}\text { Andarwulan et al., } 2012 \\
\text { Juan-Badaturuge et al., } 2011\end{array}$ \\
\hline Kampferol & $\begin{array}{l}\text { Sesbania grandiflora } \\
\text { Cassia auriculata }\end{array}$ & $\begin{array}{l}0.18^{*} \\
\text { Not given }\end{array}$ & $\begin{array}{l}\text { Andarwulan et al., } 2012 \\
\text { Juan-Badaturuge et al., } 2011\end{array}$ \\
\hline $\begin{array}{l}\text { anthraquinone glycosides } \\
\text { terpenoid glycosides } \\
\text { protoanthocyanidin } \\
\text { phenolic acids }\end{array}$ & Cassia auriculata & Not given & Surveswaran et al., 2007 \\
\hline $\begin{array}{l}\text { salicylic acid } \\
\text { vanilic acid }\end{array}$ & Amaranth tricolor & $\begin{array}{l}0.02^{*} \\
0.01^{*}\end{array}$ & Khanam et al., 2013 \\
\hline $\begin{array}{l}\text { vitexin } \\
\text { isovitexin } \\
\text { isoorientin }\end{array}$ & Passiflora edulis & $\begin{array}{l}0.40 \\
0.50 \\
1.05\end{array}$ & $\begin{array}{l}\text { da Silva et al., 2013; Ferreres et } \\
\text { al., } 2007\end{array}$ \\
\hline \multirow[t]{3}{*}{ Rutin (quercetin-3-O-rutinoside) } & $\begin{array}{l}\text { Murraya koenigii Spreng } \\
\text { Centella asiatica }\end{array}$ & $\begin{array}{l}2.36 \\
1.92\end{array}$ & Zhang et al., 2011 \\
\hline & Amaranth tricolor & $0.003^{*}$ & Khanam et al., 2013 \\
\hline & Cassia auriculata & $0.77^{*}$ & Rao et al., 2000 \\
\hline
\end{tabular}

*mg/g fresh weight 